DOI: https://doi.org/10.24144/2409-6857.2018.1(51).442-448

УДК 657.1

\author{
Семанюк В.3.
}

\title{
ОБЛІКОВА ФІЛОСОФІЯ В СИСТЕМІ ТЕОРЕТИЧНОГО ЗНАННЯ
}

\begin{abstract}
В статті досліджено філософські аспекти теоретичного облікового знання, які є необхідною умовою побудови теорії обліку. Зміна світогляду в постіндустріальному суспільстві зумовлює необхідність перегляду та філософського осмислення місия і ролі обліку в економічній науці та суспільстві. Через дослідження онтології обліку та аналіз наукових праць зроблено спробу дати визначення обліку, адекватне його суті та ролі в постіндустріальному суспільстві, де основою та системоутворюючим фактором облікової системи стає інформачія. Саме інформаџія виступає предметом обліку та продуктом облікової системи, в чому проявляється ї дуалізм. Філософське розуміння обліку дає можливість розиирити межі його теорії, поглибити погляди вчених та практиків на облік як життєво необхідну систему в економічному житті, знайти можливості для розвитку облікових знань та їх практичного застосування у відповідності до реалій постіндустріального суспільства. Досліджено основні проблеми розвитку теорії обліку, ї̈ протиріччя з практикою і соціально-економічними реаліями постіндустріального суспільства. Зроблено акиент на необхідності впровадження результатів наукових досліджень в теорію науки. 3 иією метою запропоновано розширити межі досліджень, доповнити парадигму подвійного запису інформаиійною парадигмою, де облік трактується як особливий спосіб мислення з метою відображення економічної реальності.

Опраџювання матеріалу статті стало можливим на основі використання філософії пізнання, законів діалектики, логіки, історичного, соиіологічного та системного підходів до аналізу науки про облік та ї̈ парадигми, прогнозування розвитку обліку як складної динамічної системи, аналізу факторів консерватизму облікового співтовариства. Розвиток облікової науки неможливий без переорієнтації на систему отримання інформації інтелектуального рівня для управління, щзо потребує формування розвинутої теорії обліку на принципах теорї пізнання та філософії.
\end{abstract}

Ключові слова: облік, філософія обліку, теорія обліку, інформація, інформаџійна система, онтологія обліку, наука, діалектика, парадигма, система обліку, обліковий спосіб мислення, інформологія.

Постановка проблеми. Для адекватного відображення економічної реальності та розуміння ролі обліку в суспільному розвитку доцільно використовувати філософський аналіз як методологію теоретичних узагальнень. Логіка філософського дослідження обліку дозволяє сформувати його теоретичний базис 3 врахуванням міждисциплінарних знань, гносеологічних та онтологічних досліджень. Без формування філософських основ науки неможлива евристика наукових досліджень та адаптація знань до світоглядних постулатів людства. Філософський підхід до обліку як науки змушує нас досліджувати першопричину існування обліку, шукати універсальні принципи і закони формування науки про облік, iii місце серед інших наук та суспільної свідомості, визначити світоглядні переконання та особливості мислення в процесі облікової діяльності.

Особливо актуальними філософські дослідження обліку стають в умовах зміни

(C) Семанюк Віта Зеновіївна, к.е.н, доцент, докторант кафедри аудиту, ревізії та аналізу, Тернопільський національний економічний університет, м.Тернопіль, тел.: 0667110577, email: Kvitka_tern@ukr.net парадигми або формування нової теорії, пов'язаної зі складними трансформаціями завдань та принципів обліку. Формування нової теорії супроводжується розробкою ідей, гіпотез та фундаментальних принципів, які покажуть мету та форми існування обліку. Зміна суспільних цінностей та орієнтирів має значний вплив на облікову науку, оскільки ії прикладне значення формування інформаційних ресурсів у процесі господарської діяльності та об'єктивне відображення економічної реальності. В цілому філософія дозволяє нам розуміти суть обліку як основної інформаційної системи господарської діяльності, його зв'язок з економічними явищами i процесами, осмислити тенденції та закономірності його розвитку.

Аналіз останніх досліджень і публікацій. Аналіз літератури показує, що існує мало досліджень філософії обліку. Основну увагу філософським аспектам облікового знання приділяють такі вчені: М. С. Пушкар, Ф. Ф.Бутинець, О. М. Петрук, С. Ф. Легенчук, I. М. Ткачук, А. В. Шайкан, Н. I. Петренко, М. В. Миронюк, Т. В. Бочуля, В. С. Плотніков, О. В. Плотнікова, Д. Мунітц та ін. Праці Пушкаря М.С. та Легенчука С.Ф. піднімають проблему філософського знання в обліку та 
дозволяють нам зрозуміти важливість подальших пошуків істини в цьому контексті. Професор Пушкар М.С. основними концепціями наукового пізнання в обліку вважає аксіологію та гносеологію, а суть обліку виражає через епістемологію та онтологію [1]. Легенчук С.Ф. розглядає філософські основи обліку за аналогією 3 фізикою, розвиваючи енергоентропійний підхід в теорії обліку [2]. Розвиток теорії обліку в умовах постіндустріального суспільства вимагає від дослідників теоретичних основ обліку поглиблення філософських основ облікової науки.

Формулювання цілей статті. Метою дослідження є пошук світоглядних установок та філософських основ облікової теорії крізь призму філософії економіки та специфіки філософського знання. Розвиток філософського підходу до обліку дозволить поглибити розуміння облікової діяльності, яка у філософському розумінні виходить за межі раціонального осягнення i являє собою особливий спосіб мислення та відображення економічної реальності.

Опис основного матеріалу дослідження. Філософія обліку $є$ передумовою розвитку його теорії, сприяє розумінню самої суті обліку і його розвитку відносно часу, простору, руху та інших онтологічних категорій, розкриває можливості розширення предметного поля, об'єктів, методології, дає відповіді на питання про призначення, зміст, функції обліку та вимагає дослідження концептуальних основ.

Сутність, сенс і цінності - основні філософські категорії обліку, які змінюються в залежності від зміни суспільно-історичних формацій, форм та способів ведення економічної діяльності. Історичний аналіз розвитку науки про облік показує, що в основному вона розвивалася в позитивному руслі, що означає пізнання економічних явищ i процесів, відображення фактичного стану капіталу та зобов'язань господарюючого суб'єкта.

За товарної форми господарювання метою обліку була інформація для задоволення внутрішніх потреб управлінців. Товарні форми виробництва та поява контрагентів, клієнтів, кредиторів - вимагали від обліку інформації про загальний фінансовий стан бізнесу. Планова економіка поставила облікову систему в залежність від державного регулювання i задоволення фіскальних потреб держави. Ринкова економіка 3 ii динамічністю та відкритістю вимагає інформації про внутрішнє та зовнішнє середовище підприємства, для оперативного управління ним та побудови ефективної стратегії розвитку.
Облік функціонує в певних просторовочасових межах відносно господарської діяльності і представлений квартетом «людина природа - господарська діяльність інформація», який має вплив на формування базових цінностей облікової науки. Облік, похідний від наявної економічно-соціальної ситуації, обслуговує певну економіко-соціальну формацію.

Облікова наука як частина загального циклу економічних наук - це сфера розумової діяльності людини, філософією та основною метою якої $\epsilon$ моделювання облікової картини світу (відображення об'єктивної економічної реальності). Кардинальні зміни в суспільноекономічній формації людства змушують облікову науку до перегляду своїх цінностей, факторів впливу, категорій та фундаментальних принципів, істинності наукових положень.

Господарська діяльність - це потік певних подій і фактів, які утворюють собою певну послідовність. Завдання обліку та його основна концептуальна функція - відображати ці події шляхом узагальнення та трансформації даних i перетворення ㄲï в інформацію та знання. Економічна діяльність це співпраця множини суб'єктів та індивідів з оточуючим середовищем i один 3 одним. Основою цієї співпраці $\epsilon$ інформація, а результатом - сукупність економічних та соціальних зв'язків. Філософські закони та категорії є основою пізнання облікових принципів та його суті як соціального та економічного явища.

Керуючись формальною та неформальною логікою, виявимо властивості обліку, розглянемо його як економічне та соціальне явище, в діалектичних та метафізичних категоріях. Діалектика як метод наведення аргументів та теоретичне рефлексивне мислення дозволить нам виявити можливі протиріччя та суперечності в розвитку облікової науки. Основою діалектичного підходу до обліку мають стати також поняття етики та істини. На противагу діалектичній методології метафізика прагне дослідити певне «начало». Облік у світлі метафізики має раціональну епістемну природу, a його дослідження можуть проводитися лише методами формальної логіки. Епістемна природа облікового знання означає рівень розуміння природи об'єкта дослідження та його відповідність реальній природі, а також обгрунтованість та істинність наукових знань

Категорії істини іноді змінюють категоріями достовірності, правдивості, змісту тощо. Проте саме істина $є$ основним поняттям гносеології, адже основним критерієм істини є емпіричні доведення, які грунтується на достовірному 
спостереженні.

Гострі проблеми індустріального характеру приводять до необхідності зміни визначення самого процесу управління економікою в цілому та підприємством зокрема. Наука спонукає до розвитку сфер виробництва, регулює іiі, перебудовує засоби і предмети праці. Які ціннісні орієнтації науки про облік? Відповідь треба знайти для успішних подальших досліджень.

Облікова онтологія це розуміння об'єктивної природи обліку, його сутності, що вважається найбільш складним і важливим питанням науки. Без його вирішення неможливе розуміння обліку як універсальної категорії буття, його відношення $з$ основними субстанціями всесвіту: речовиною, енергією, інформацією, де облік, як інформаційна система має за мету відобразити інформацію про речовину (матеріальні об'єкти) та енергію (нематеріальні об'єкти та процеси). Бізнес як джерело створення благ та отримання доходу володіє різними видами капіталу, здійснює числення транзакції, прагне до отримання цілісної картини своєї діяльності в багатьох вимірах i розрізах. Як за допомогою подвійного запису визначити результат? Дуже складно, незважаючи на те, що в обліковій системі відбувається моніторинг і фіксація усіх бізнес-операцій, процесів, подій.

Синергетична парадигма внесла в науку новий стиль мислення, нове бачення світу як нестабільного середовища, невизначеність i альтернативи розвитку виникнення порядку 3 хаосу. Досліджуючи онтологічну суть обліку економічної діяльності в світлі синергетичної парадигми, ми мусимо визнати, що це не подвійний запис, «Дебет», «Кредит», а окрема філософія, система чи то форма мислення, специфічно організована 3 метою отримання нової інформації та нових знань про об'єкт дослідження. Систему ж подвійного запису догматично відстоюють протягом століть.

Важко в сучасній літературі знайти грунтовне дослідження дефініції «облік». Чому облік в економічному розумінні називають бухгалтерським i чи задумувалися колись бухгалтери що таке облік?

Тлумачний словник української мови дає нам такі визначення дефініції «облік»:

-засвідчення, встановлення наявності, 3'ясування кількості чого-небудь;

- реєстрація осіб із занесенням даних про них у відповідні списки;

- система реєстрації показників процесів якоїнебудь діяльності у їх кількісному та якісному виявах з метою контролю, спрямування тощо [3].

В третьому визначенні, яке $\epsilon$ найбільш близьким до теми нашого дослідження, хочемо підкреслити словосполучення «якої-небудь діяльності», тобто не лише економічної, а й астрономічної (ведеться ж реєстрація та облік зірок, комет, затемнень тощо), біологічної (облік популяцій тварин та ареалів рослин), демографії (облік населення). Чому ці види обліку не називають бухгалтерським?

Поняття «облік» $є$ дефініцією, яка позначає специфічний вид діяльності, пов'язаний 3 інформаційним відображенням процесів, подій, явищ тощо. Облік у сфері економічної діяльності обмежується інформаційним відображенням економічної дійсності та пов'язаних 3 нею процесів і явищ. Аналогічну ситуацію можемо спостерігати в інших науках, наприклад арифметика i математика, арифметика $\epsilon$ частиною математики, але ж не окремою наукою. Аналогічно облік економічний $\epsilon$ частиною онтологічного поняття «облік».

Вітчизняні науковці називають весь процес інформаційного відображення економічної дійсності - облік, а науку про облік бухгалтерським, використовуючи про цьому давно застарілі терміни «оперативний», «статистичний» та й нові, запозичені у зарубіжних дослідників, «фінансовий», «управлінський», «стратегічний», створюючи тим самим джерело безкінечного хаосу в термінології, що заважає пізнати суть самого обліку, як явища.

Зустрічаються навіть такі назви як «Бухгалтерський фінансовий облік» або «Бухгалтерський управлінський облік», які викликають дисонанс i повністю нівелюють розуміння понять. Якщо ж автори цих термінів вважають, що дефініцію «бухгалтерський» треба зберегти як таку, що має історичну цінність, то таку позицію ще можна зрозуміти, хоча ми не прихильники історичних назв, які були адекватними для облікових систем відповідних історичних періодів. В умовах розвитку суспільства поняття «облік» змінювалося залежно від зміни рівня економічного чи суспільного розвитку, чи то розвитку певних цивілізаційних формацій. Сучасна економічна система і облікова наука вимагають кардинально нових підходів, нових визначень i дефініцій. «Порівнюючи наведені визначення слова «облік» 3 традиційно вживаною назвою науки, яку назвали «бухгалтерським обліком» - професор Пушкар М.С. зазначає - неупереджена людина розуміє, що тут є щось нелогічне, а саме, як зазначають філософи, маємо підміну понять [4].

Вивчення походження назв чи термінів в науці, дослідження етимології слів дозволяє виявити прості форми контексту, які $\epsilon$ 
підгрунтям для більш складних наукових контекстів. Саме тому облікова термінологія в цілому та назва науки зокрема потребують перегляду та доповнення на основі історичнологічного дискурсу, що дасть глибше розуміння співвідношень між різними визначеннями і змістами.

Джон Остін стверджує, що слову ніколи не позбутися своєї етимології, а всі зміни чи доповнення до значення слова опираються на першоідею. Повертаючись до історії слова, часто в латинському вираженні, ми приходимо до картин чи моделей, які описують цілком зрозумілі явища [5]. Так, слово бухгалтерський дає нам уяву про книгу, а отже, книжний облік, який ведеться в книгах.

Замість того, щоб розкрити речі, об'єкти, явища, процеси тощо, які відображає зміст науки, акцент зроблено на інше - на якому матеріальному носієві здійснюють облік, тобто у книгах, що дослівно означає «книжний облік». У такій назві науки втрачається об'єкт дослідження, сфера людської діяльності, сутність, зміст, категорії та ін.» [6]. Якщо назву «бухгалтерський» облік у середні віки до певної міри можна було зрозуміти, оскільки книги i записи в них служили юридичним доказом здійснених фактів, а книги реєстрували нотаріуси і засвідчували підписом і печаткою, то в наші дні цього не роблять і робити не будуть.

В останні десятиріччя склалася ситуація, коли невідповідність назви науки потребам розвитку змісту облікового процесу гальмує не лише наукові дослідження, а й практичне використання інформації, яку генерує облік. В якості компромісного варіанту назви облікової науки пропонується словосполучення «господарський облік», яке вказує на обмеження інформаційного поля господарською діяльністю підприємства, але і в цьому випадку не ясно, що підлягає обліку.

Не можна заперечувати, що облік це наука, оскільки містить систематизоване знання, базується на визначених принципах тощо. Та для цілісного розуміння сутності обліку i його адекватної інтерпретації зазначимо, що практика ведення записів (record keeping) існувала задовго до виникнення методології подвійного запису. Е. Кохлер, В.Купер, Ю. Іджірі (Kohler E. L., Cooper, W. W., \& Ijiri, Y. ) в “Словник для бухгалтерів» визначають «Book keeping» як «процес аналізування, класифікації i запису трансакцій відповідно визначеного порядку» [7], a P. Картер (R. Carter) в книзі «Advanced accounting» [8] визначає облік як науку i як мистецтво записів, також виділяючи «Book keeping» як мистецтво записів та «accounting» як інтерпретацію фактів.

Отже, зарубіжна облікова наука володіє двома термінами:

- bookkeeping (англ.), bochhaltung (нім), knigovodstvo (серб.), ksengowost (пол.) реєстрація фактів або мистецтво записів;

- accounting (англ.), rechnungswesen (нім.), rachunkowosc (пол.) - система створення інформації, думка, процес мислення .

Економічна енциклопедія дає таке визначення: «Облік - складова управління економічними процесами й об'єктами обліку фіксація їх стану та основних параметрів, збору й накопичення даних про економічні об'єкти i процеси, їх відображення в облікових відомостях. Розрізняють облік аналітичний, бухгалтерський, підприємств і установ, бюджетний, синтетичний, фінансовий, управлінський та ін.» [9]. В цьому ж виданні зустрічаємо такі дефініції як «Облік боргових вимог», «облік доходів і витрат», «облік майна», «облік оперативний», «облік первинний», «облік податковий», «облік синтетичний», «облік табельний», «облік фінансовий», «облік управлінський». Як розуміти нам ці всі види обліку, чи правомірно їх виділяти, які зв'язки між ними і чи вони існують? Багато питань виникає, та основне: Чи можна ці всі види обліку назвати бухгалтерським?

Відповіді на питання, які ставить життя, являють собою сукупність принципів, підходів, концептуальних поглядів на те, як вирішувати оперативні, тактичні і стратегічні завдання. При цьому моделі обліку постійно вдосконалюються, трансформуються i перетворюються у відповідності зі змінами які відбуваються. В умовах швидкого суспільного розвитку недостатньо таких трактувань та визначень обліку, які ми зустрічаємо в сучасних підручниках 3 теорії: «Облік це кількісне відображення i якісна характеристика господарської діяльності 3 метою управління нею» (визначення взято нами навмання, адже всі вони практично несуть один i той же зміст). Визначення обліку дозволяє нам бачити його завдання і функції. Множинність таких завдань породжує множину визначень, які ми можемо знайти в науковій та навчальній літературі. Проте детальний аналіз усіх визначень показує, що жодне 3 них не відображає суті обліку, його онтологічного змісту.

Наукове знання передбачає фіксацію об'єкта, основних законів його існування, виявлення необхідних, достовірних зв'язків в процесах i явищах. Тому визначення обліку повинно розкривати всі його аспекти як системи, показувати облік не лише як функцію 
управління, а й як науку, як об’єкт права, як елемент соціального, економічного та суспільного устрою, адже через відсутність глибокого теоретичного обгрунтування облікової системи та іiі підсистем існують різні розуміння одних і тих же понять, категорій і навіть об'єктів обліку.

Панков Д.І., Верега С.Г. визначають бухгалтерський облік як «особливу сферу людської діяльності і .... унікальний, єдиний в своєму роді і суспільно визнаний методичний інструмент економіко-правового узгодження економічних інтересів всіх учасників бізнесу 3 приводу справедливого розподілу зароблених доходів на рівні окремо взятого суб'єкта господарювання» [10].

М.Р. Лучко, даючи визначенню обліку i називаючи його традиційно бухгалтерським, слушно зауважує, що це «...складна, створена знаннями, інтелектом та свідомістю людини, система виміру, реєстрації, збору, обробки, аналізу i представлення даних про активи, капітал та зобов'язання підприємства під впливом господарських подій [11, с. 21].

М.Ю. Медведев використовує термін «екаунтологія» (від англ. account - рахунок, гр. $\operatorname{logos}$ - слово, поняття, вчення), розуміючи під ним науку, яка вивчає універсальні можливості обліку, незалежно від бухгалтерського обліку, в першу чергу відносно комп'ютерних баз даних[12]. Завданням екаунтології автор вважає заміну застарілої методології, яка грунтується на використанні облікових книг, на новітню методологію, яка базується на використанні комп'ютерних баз даних. Проте, сам автор стверджує, що екаунтологія являє собою синтетичну дисципліну, яка міститься на стику бухгалтерського обліку, філософії, інформатики і економіки i складається 3 трьох частин: філософської, методологічної, економічної. Незважаючи на раціональні моменти представленого розуміння дефініцій, мусимо визнати, що такий підхід не може претендувати на цілісну теорію обліку.

Професор Пушкар М.С., відомий своїм новаторським i нестандартним підходом до облікової науки, неодноразово підкреслював невідповідність назви науки про облік ії змісту в умовах розвитку суспільства. В монографії «Ідеальна система обліку: концепція, архітектура, інформація» професор Пушкар М.С. пропонує до використання термін «інформологія» [13], розуміючи під ним науку про створення уяви про діяльність підприємства за допомогою отриманої інформації. 3 огляду на таке визначення автора ми цілком погоджуємося 3 тим, що облікова наука потребує модернізації не лише свого змісту, а й назви, оскільки сама назва «бухгалтерський» спонукає до розуміння обліку, як книжної системи узагальнення інформації.

Разом 3 тим, в загальному циклі наук про інформацію, інформологію розуміють як узагальнену назву наук про інформацію в сучасному світі, до числа яких належать теорія інформації, кібернетика, логіка, семіотика, багато лінгвістичних, гуманітарних і суспільних наук.

Інформатика - це наука про інформацію та інформаційні процеси в природі та суспільстві, методи та засоби пошуку, збирання, одержання, опрацювання, зберігання, подання, передавання інформації та управління інформаційними процесами. Інформологія $є$ фундаментальним знанням щодо інформатики $\mathrm{i}$ трактується як наука про інформацію та вивчення закономірностей, загальних для всіх типів інформації, які існують в соціумі, техносфері, в живій і неживій природі. Зрозуміло, що поняття обліку цілком підпадає під це визначення, проте облік $є$ лише частиною наук, які досліджує інформологія, а тому не може називатися інформологією, адже інформація створювана в системі обліку висвічує лише частину проблем певної широкої системи знань, яку називають загальною теорією інформації або інформологією - наука про процеси і завдання передачі, розподілу, обробки i перетворення інформації.

Професор Пушкар М.С. аналогічно зазначає, що інформологія (мається на увазі облікова наука - В.С.) є частиною науки, яку відносять до прикладної інформатики, пов'язаної із теорією i практикою створення i використання інформаційних технологій для постійного моніторингу фактичного стану об'єктів господарської діяльності підприємства у просторовому і часовому вимірі [4, С. 91-92]. Досліджуючи облік як об'єктивне економічне поняття ми маємо справу 3 постійно функціонуючим процесом моніторингу зовнішнього i внутрішнього середовища діяльності економічних агентів i створення інформації про цю середовищі спеціальними методами, основою розробки яких стане особливий економічний спосіб мислення.

Разом $з$ тим зазначимо, що облік є унікальним поняттям, оскільки його можна розглядати як теоретичну абстракцію об'єктивне економічне явище, a 3 іншого боку - як матеріальну субстанцію (практичну діяльність) i процес, продуктом якого $€$ інформаційні ресурси. Використання облікових методів призводить до відображення економічної реальності, пояснення 
і прогнозування економічних явищ.

Усі визначення обліку, сформовані в межах парадигми подвійного запису, не враховують того, що більшість управлінських рішень приймаються в умовах ризику і невизначеності, обумовлені як об'єктивними так і суб'єктивними факторами ендогенними і екзогенними впливами на підприємство. Ця обставина приводить нас до думки, що для прийняття управлінських рішень потрібна інформація не тільки про внутрішне середовище функціонування бізнесу, а й про зовнішне.

Розширюючи парадигму обліку в постіндустріальному суспільстві трактуємо облік як особливий спосіб мислення, економічну метрологію, специфічну мову для інформаційного відображення економічної реальності 3 ii недоліками та досягненнями. Завданням обліку є надання змісту всім процесам економічної діяльності, адже коли ми говоримо про спотворення звітності, то це може бути не лише спотворення чисел у звітних формах, а й невідповідна реальності облікова мова.

Висновки i перспективи подальших досліджень. Інформаційний супровід процесу управління підприємством - це складний механізм створення інформаційних ресурсів, потрібних для прийняття рішень. Філософський підхід до облікової науки дозволить сформувати його теоретичне підгрунтя, дасть розуміння обліку як онтологічної категорії, розширить поле облікових досліджень та відповість на виклики сучасного інформаційного суспільства.

Дефініція «бухгалтерський облік» не відповідає вимогам часу і не передає суті обліку, зводячи його лише до реєстрації фактів в процедурному аспекті. В українській мові відсутній аналог слова accounting, який несе в собі глибший зміст і виводить облікову науку на якісно новий рівень розвитку. Ми не можемо дати однозначної відповіді щодо назви науки, проте порушуємо цю проблему, наголошуючи на тому, що розуміння обліку в філософському аспекті вимагає від науковців певного стилю мислення та прагнення до пізнання економічної реальності та іï адекватного інформаційного відображення в системі обліку.

Сучасні визначення обліку показують його емпіричний рівень, натомість ми прагнемо до формулювання таких дефініцій, які можливості обліку формувати судження про речі, явища i процеси економічної реальності, що являє собою вищий рівень пізнання. Запропоноване нами визначення не претендує на остаточну редакцію, проте відображає здатності обліку до створення інформації, зниження рівня ентропії, перетворення хаосу у порядок. В основу облікової системи постіндустріального суспільства ми пропонуємо ставити інформаційну парадигму, де інформація стає системоутворючим фактором та результатом функціонування цієї системи.

Перспективи подальших досліджень полягають у необхідності нового формулювання обліку та розширення меж облікової парадигми, створенні теорії обліку відповідної постіндустріальному суспільству, розвитку методології та визначенні нових об'єктів обліку. Запити користувачів та їх інформаційних потреб в якісній, своєчасній та надійній інформації приводять до неминучого росту ролі облікової системи в управлінні, що змушує дослідників звертатися до філософських методів дослідження та визначення онтологічної суті обліку і його місця в системі економічних та суспільних наук.

\section{ПЕРЕЛІК ВИКОРИСТАНИХ ДЖЕРЕЛ}

1. Пушкар М. С. Філософія обліку / М. С. Пушкар. - Тернопіль : Карт-Бланш, 2002. - 157 с.

2. Легенчук С.Ф. Теорія і методологія бухгалтерського обліку в умовах постіндустріальної економіки : монографія / С.Ф.Легенчук - Житомир : ЖДТУ, 2010. - С.487

3. Новий тлумачний словник сучасної української мови / Уклад.: Радченко І.О., Орлова О.М. - К.: ПП Голяка В.М., 2007. - 768 с. - С. 431

4. Пушкар М. С. Ідеальна система обліку : концепція, архітектура, інформація : монографія / М.С. Пушкар, М.Г. Чумаченко. - Тернопіль : Карт-бланш, 2011. - 336 с.

5. Austin J. L. Philosophical Papers. Oxford: Clarendon Press. 1961, P. 149

6. Пушкар М. С. Актуальність розробки сучасної парадигми обліку / М.С. Пушкар, В.3. Семанюк // Інститут бухгалтерського обліку, контроль та аналіз в умовах глобалізації: Міжнародний науковий журнал, Випуск 1-2.- 2017 - С. 7-20.

7. Kohler, E. Louis. (1983). Kohler's Dictionary for accountants. 6th ed. Englewood Cliffs, N.J.: Prentice-Hall.

8. Carter R. N. (1923). Advanced Accounts: a manual of advanced bookkeeping and accountancy for accountants, book-keepers and business men. Edited by R.N. Carter. London, Pitman \& Sons.

9. Економічна енциклопедія / Відповідальний редактор С.В. Мочерний. - Київ: Видавничий центр «Академія». - Т. 1, 2000. - С.607-608

10. Панков Д.А., Вегера С.Г. Методология бухгалтерского учета: диалектика научного познания и проблема научного результата // Международный бухгалтерский учет. 2012. №14. С.2-15 
11. Лучко М. Р. Пізнання в розвитку теорії бухгалтерського обліку / М. Р. Лучко // Науковий вісник Ужгородського університету - 2015 - Серія "Економіка". Випуск 1 (45). Т.2 - С. 33-38

12. Медведев М.Ю. Экаунтология: Компьютерный учет вместо бухгалтерского / М.Ю. Медведев. - М.: ДМК. Пресс, 2012. - С.15

\section{REFERENCES}

1. Pushkar, M. S. (2002) Filosofiia obliku [The philosophy of accounting] - Ternopil : Kart-Blansh [in Ukrainian].

2. Lehenchuk, S.F. (2010) Teoriia i metodolohiia bukhhalters'koho obliku v umovakh postindustrial'noi ekonomiky: Monohrafiia [Theory and methodology of accounting in a post-industrial economy] - Zhytomyr : ZhDTU [in Ukrainian].

3. Radchenko, I. O., \& Orlova, O. M.( 2007) Novyi tlumachnyi slovnyk suchasnoi ukrainskoi movy [New glossary of modern Ukrainian language] - K.: PP Holiaka V.M. [in Ukrainian].

4. Pushkar, M. S. \& Chumachenko, M. H. (2011) Idealna systema obliku: kontseptsiia, arkhitektura, informatsiia : monohrafiia [Ideal accounting system: concept, architecture, information] - Ternopil : Kart-blansh [in Ukrainian].

5. Austin, J. L. (1961) Philosophical Papers. Oxford: Clarendon Press.

6. Pushkar, M.S. \& Semanyuk, V.Z. (2017) Aktualnist rozrobky suchasnoi paradyhmy obliku [Research on actuality of up-to-date accounting paradigm] Instytut bukhhalters'koho obliku, kontrol' ta analiz $v$ umovakh hlobalizatsiyi. Mizhnarodnyy naukovyy zhurnal - The Institute of Accounting, Control and Analysis in the Globalization Circumstances. International scientific journal, Vol. 1-2, 7-20 [in Ukrainian].

7. Kohler, E. Louis. (1983). Kohler's Dictionary for accountants. 6th ed. Englewood Cliffs, N.J.: Prentice-Hall.

8. Carter, R. N. (1923). Advanced Accounts: a manual of advanced bookkeeping and accountancy for accountants, book-keepers and business men. Edited by R.N. Carter. London, Pitman \& Sons.

9. Mochernyi, S.V. et al. (2000) Ekonomichna entsyklopediia [Economic Encyclopedia] - Kyiv: Vydavnychyi tsentr «Akademiia» [in Ukrainian].

10. Pankov, D. A. \&Vehera, S. H. (2012) Metodolohyia bukhhalterskoho ucheta: dyalektyka nauchnoho poznanyia y problema nauchnoho rezultata [Accounting methodology: the dialectic of scientific knowledge and the problem of scientific result] Mezhdunarodnyiy buhgalterskiy uchet. - International Accounting, 14, 2-15 [in Russian].

11. Luchko M. R. (2015) Piznannia v rozvytku teorii bukhhalterskoho obliku [Cognition in the development of the theory of accounting] Naukovyi visnyk Uzhhorodskoho universytetu. Seriia "Ekonomika". - Scientific Bulletin of Uzhhorod University, Series "Economics", Vypusk 1 (45), T.2, 33-38 [in Ukrainian].

12. Medvedev M.Yu. (2012) Ekauntologiya: Kompyuternyiy uchet vmesto buhgalterskogo [Accountancy: Computer accounting instead of accounting]. - M.: DMK. Press, 2012. - S.15 [in Russian].

Одержано 15.03.2018 p. 